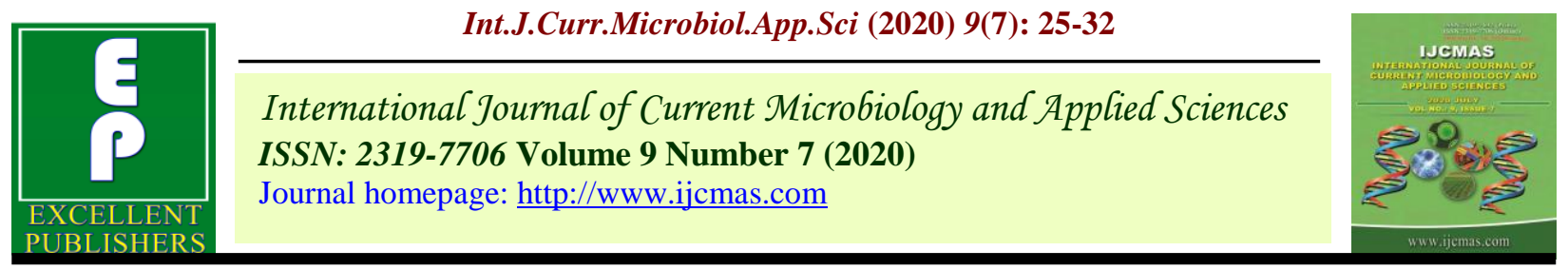

Original Research Article

https://doi.org/10.20546/ijcmas.2020.907.004

\title{
Role of Growth Regulators on Fenugreek (Trigonella foenum-graecum L.)
}

\author{
Peddaveeri Pravalika Reddy ${ }^{1}$ and J.K. Hore*
}

Department of Plantation, Spices, Medicinal and Aromatic Crops, Faculty of Horticulture, Bidhan Chandra KrishiViswavidyalaya, Mohanpur-741252, Nadia, West Bengal, India

*Corresponding author

\begin{tabular}{l} 
Ke y w o r d s \\
$\begin{array}{l}\text { Fenugreek, Growth, } \\
\text { Plant growth } \\
\text { regulators, Yield }\end{array}$ \\
\hline Article Info \\
\hline $\begin{array}{l}\text { Accepted: } \\
\text { 05 June } 2020 \\
\text { Available Online: } \\
\text { 10 July } 2020\end{array}$ \\
\hline
\end{tabular}

\section{Introduction}

Fenugreek (Trigonella foenum-graecum L.) is one of the most important seed spice crop cultivated throughout the world for seed, green leafy vegetable and forage purpose. The crop belongs to family Fabaceae of sub family Papillionaceae and the order Fabales (Petropoulos, 2002). Apart from its spice value, fenugreek is a valuable source of several highly desirable biologically active compounds such as galactomannan (Brummer et al., 2003), diosgenin (Fazli and Hardman, 1968), 4-hydroxy- isoleucine (Fowden et al., 1973) and trigonelline (Antony and Gopinathan, 1975) that have specific health benefits. India is the largest producer of fenugreek. The crop coverage in India was 1, 24,710 ha with a production of 134,100 metric tonnes; the average productivity of the country was $1075 \mathrm{~kg} \mathrm{ha}^{-1}$ during 2014-15 (Spice board, 2015). Rajasthan, Gujarat, 
Haryana, Uttar Pradesh and Uttarakhandare the important states for fenugreek under irrigated conditions.

It is also cultivated in the states of West Bengal, Madhya Pradesh, Bihar, Orissa, Karnataka and Andhra Pradesh to a limited extent mostly under supplementary or without irrigation (Sastry and Anandraj, 2013). In spite of its large scale cultivation in India, the productivity of these crops is low, mainly due to the paucity of high yielding varieties, inadequate access of the good seeds to the growers and lack of improved management practices. The productivity can be increased, if a proper combination of the varieties and management are available to the growers.

Plant growth regulators present a new possibility to break yield barrier, particularly imposed by the environment (Witter, 1971). The plant growth regulators act as chemical catalysts in plants and improve physiological and reproductive efficiency in the plants. The plant growth regulators possibly improve the gene expression for efficient sucrose transport and increase dry matter partitioning for seed production. Effectiveness of plant growth regulators depends on several factors viz., concentration, method and time of application etc. It is established fact that plant growth regulators in small quantity can regulate various physiological processes (Saxena, 1989) but information regarding the suitability of various plant growth regulators and their time of application for fenugreek is very limited. With this background the present experiment was undertaken to identify the suitable growth regulators and the concentration for maximization the seed yield of fenugreek under alluvial plains of West Bengal.

\section{Materials and Methods}

The present investigation was carried out during winter season of two consecutive years i.e. 2016-17 and 2017-18 at Horticultural Research Station, BidhanChandra Krishi Viswavidyalaya, Mondouri, West Bengal. The research station was located at $23.5^{\circ} \mathrm{N}$ latitude and $89^{\circ} \mathrm{E}$ longitude, with an altitude of $9.75 \mathrm{~m}$ above the mean sea level. The experiment consisting of five growth regulators along with three concentration namely $\mathrm{GA}_{3}(50,100$ and $150 \mathrm{ppm})$, NAA (25, 50 and 75 ppm), Ethrel (100, 150 and $200 \mathrm{ppm}$ ), Maleic hydrazide (500, 1000 and $1500 \mathrm{ppm})$ and Thiourea (250, 500 and 750 ppm). The experiment was laid out in Randomized Block Design with three replications. Seeds were sown in the plot of $2 \mathrm{~m} \times 1.5 \mathrm{~m}$ at spacing of $30 \times 20 \mathrm{~cm}$. A fertilizer dose of $15 \mathrm{t} \mathrm{ha}^{-1}$ of farmyard

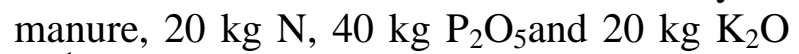
$\mathrm{ha}^{-1}$ was applied. Nitrogen was applied in two equal split dose i.e., half basal and remaining dose at 30 days after the first application. The entire phosphorus and potassium were applied as basal. Growth regulators were applied as foliar spray as per the treatments at 30 and 60 days after sowing.

\section{Results and Discussion}

The experimental results (pooled data) presented in Tables 1 revealed details on plant height, primary branches per plant, secondary branches, days to $50 \%$ flowering, number of pod per plant, number of seeds per pod, seed yield per plant and projected yield showed significant variations. As shown in Fig.1 among various treatments, at 45 DAS, maximum plant height $(41.26 \mathrm{~cm})$ was recorded in plants treated with $\mathrm{GA}_{3} 150 \mathrm{ppm}$ followed by ethrel $200 \mathrm{ppm}(38.64 \mathrm{~cm})$ and $\mathrm{GA}_{3} 100 \mathrm{ppm}(38.24 \mathrm{~cm})$ as compared to minimum plant height of $25.82 \mathrm{~cm}$ in maleic hydrazide $1500 \mathrm{ppm}$. At $105 \mathrm{DAS}$, the plant height ranged between 76.34 to $98.32 \mathrm{~cm}$. The maximum plant height was observed in $\mathrm{GA}_{3} 100 \mathrm{ppm}$ followed by thiourea $500 \mathrm{ppm}$ $(93.74 \mathrm{~cm})$ as compared to minimum plant height of $76.34 \mathrm{~cm}$ in maleic hydrazide 1500 
ppm. The maximum number of primary branches (5.41) at 45 DAS was recorded with $\mathrm{GA}_{3} 100 \mathrm{ppm}$ followed by NAA $75 \mathrm{ppm}$ (5.28) and NAA 50 ppm (5.16) as compared to minimum branches (4.18) with ethrel 100 ppm as shown in Fig. 2. At 105 DAS, the maximum number of primary branches (8.46) was noticed in thiourea $500 \mathrm{ppm}$ followed by $\mathrm{GA}_{3} 100$ ppm (8.24) and NAA 75 ppm (8.15) as compared to minimum number of branches in control (6.47).

The plants sprayed with thiourea 500 ppm recorded maximum number of secondary branches plant ${ }^{-1}$ (8.46) and ethrel 200 ppm (8.06) against the minimum number of branches in control plants at 105 DAS (Fig.3). As represented in the Fig.4, minimum duration of 48.24 days required for initiation of $50 \%$ flowering with NAA 75 ppm followed by ethrel 200 ppm (51.26 days) and $\mathrm{GA}_{3} 50$ ppm (51.76 days) as compared to the longest time required for $50 \%$ flowering in maleic hydrazide 1500 ppm (65.24 days) followed by thiourea 750 ppm (63.24 days). Required time for control plants was 58.24 days. In $\mathrm{GA}_{3}$, maleic hydrazide and thiourea, with increasing the concentration the duration was increasing for initiation of $50 \%$ flowering. However, the opposite trend was noticed with NAA and ethreli.e., with the increasing concentration the duration required became shortened. Maximum number of pods plant ${ }^{-1}$ was recorded with NAA 75 ppm (73.24) followed by ethrel $200 \mathrm{ppm}$ (71.42) and thiourea $500 \mathrm{ppm}(70.45)$ as compared to the minimum number of pods (51.34) under maleic hydrazide 1000 ppm. Maximum number of seeds pod $^{-1}$ was recorded under $\mathrm{GA}_{3} 100$ ppm (15.18) followed by NAA 75 ppm (15.06) and NAA $50 \mathrm{ppm}$ (14.82) as compared to minimum number of seeds pod $^{-1}$ with maleic hydrazide 1500 ppm (11.76). Seed number increased with the increase of concentration in respect of $\mathrm{GA}_{3}$ and thioureaupto medium concentration but in respect of NAA and ethrel the seed number increased with highest concentration.

Maximum seed yield plant $^{-1}$ of $16.24 \mathrm{~g}$ was recorded in NAA $75 \mathrm{ppm}$ followed by thiourea $250 \mathrm{ppm}(14.72 \mathrm{~g})$ and ethrel 200 ppm (14.52g) as compared to lowest seed yield of $9.25 \mathrm{~g}$ under maleic hydrazide 1500 ppm. The plants grown under NAA 75 ppm recorded maximum projected yield (16.31q $\left.\mathrm{ha}^{-1}\right)$ followed by thiourea $500 \mathrm{ppm}(15.69 \mathrm{q}$ $\mathrm{ha}^{-1}$ ) and ethrel $200 \mathrm{ppm}$ (15.46 $\left.\mathrm{q} \mathrm{ha}^{-1}\right)$ as compared to control (11.23 $\left.\mathrm{q} \mathrm{ha}^{-1}\right)$. The lowest yield was recorded in maleic hydrazide 1500 ppm (Fig.5).

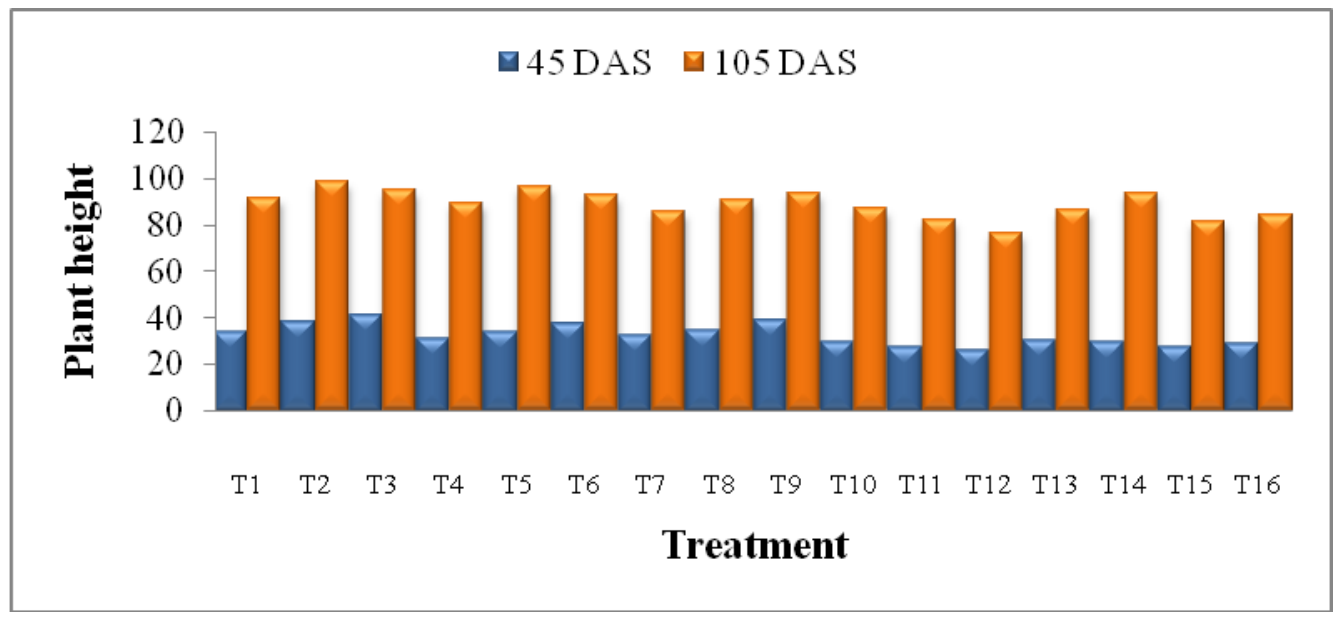

Fig.1 Effect of growth regulators on plant height of fenugreek at different stages 


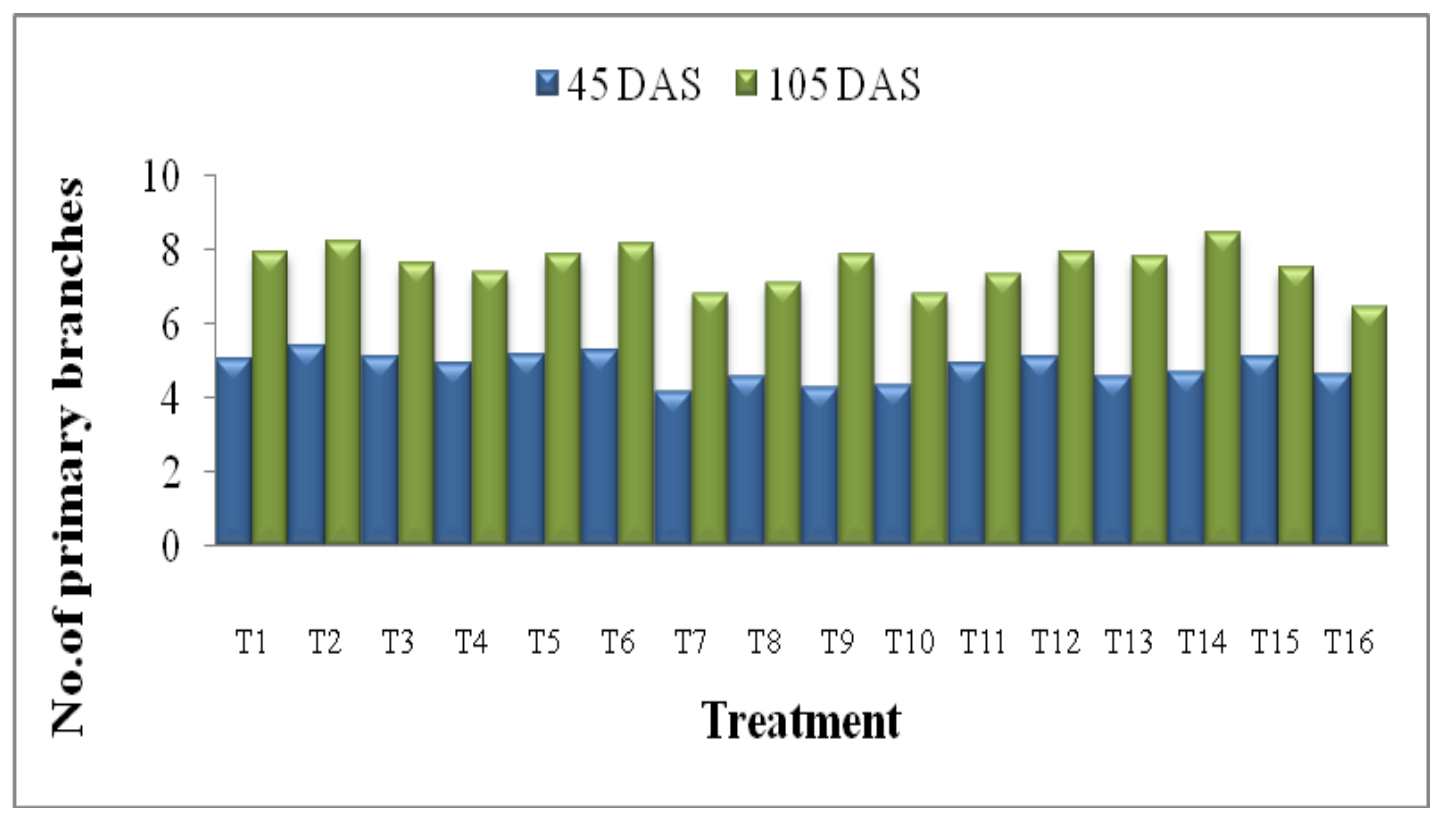

Fig.2 Effect of growth regulators on number of primary branches per plant of fenugreek

$\mathrm{T}_{1}-\mathrm{GA}_{3} 50 \mathrm{ppm}$

$\mathrm{T}_{4}$ - NAA $25 \mathrm{ppm}$

$\mathrm{T}_{2}-\mathrm{GA}_{3} 100 \mathrm{ppm}$

$\mathrm{T}_{3}-\mathrm{GA}_{3} 150 \mathrm{ppm}$

$\mathrm{T}_{7}$ - Ethrel $100 \mathrm{ppm}$

$\mathrm{T}_{5}$ - NAA $50 \mathrm{ppm}$

$\mathrm{T}_{6}$-NAA $75 \mathrm{ppm}$

$\mathrm{T}_{10^{-}}$MH $500 \mathrm{ppm}$

$\mathrm{T}_{8}$ - Ethrel $150 \mathrm{ppm}$

$\mathrm{T}_{9}$ - Ethrel $200 \mathrm{ppm}$

$\mathrm{T}_{13}$ - Thiourea $250 \mathrm{ppm} \quad \mathrm{T}_{14^{-}}$Thiourea $500 \mathrm{ppm}$

$\mathrm{T}_{12}-\mathrm{MH} 1500 \mathrm{ppm}$

$\mathrm{T}_{16}$ - Control

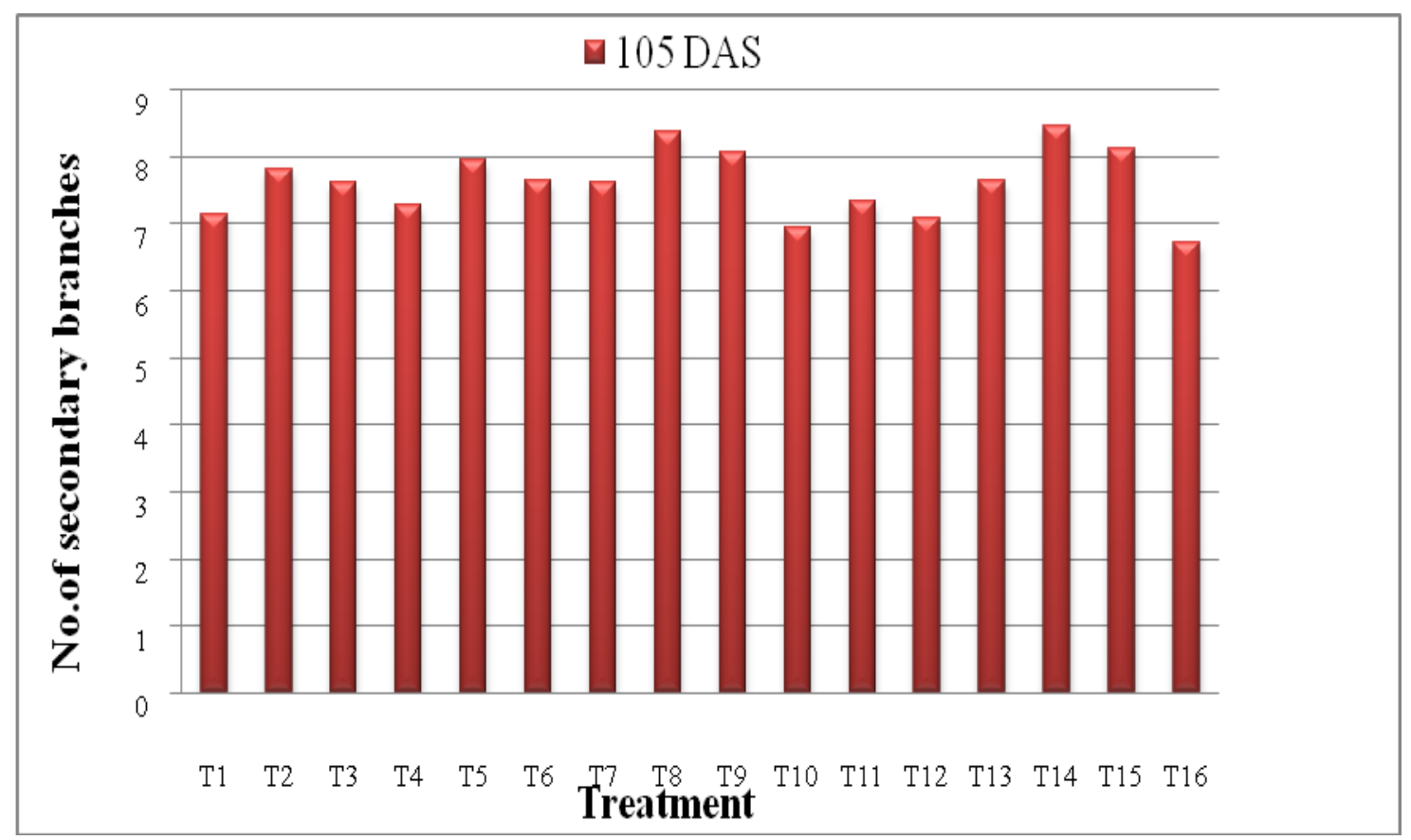

Fig.3 Effect of growth regulators on number of secondary branches per plant of fenugreek 


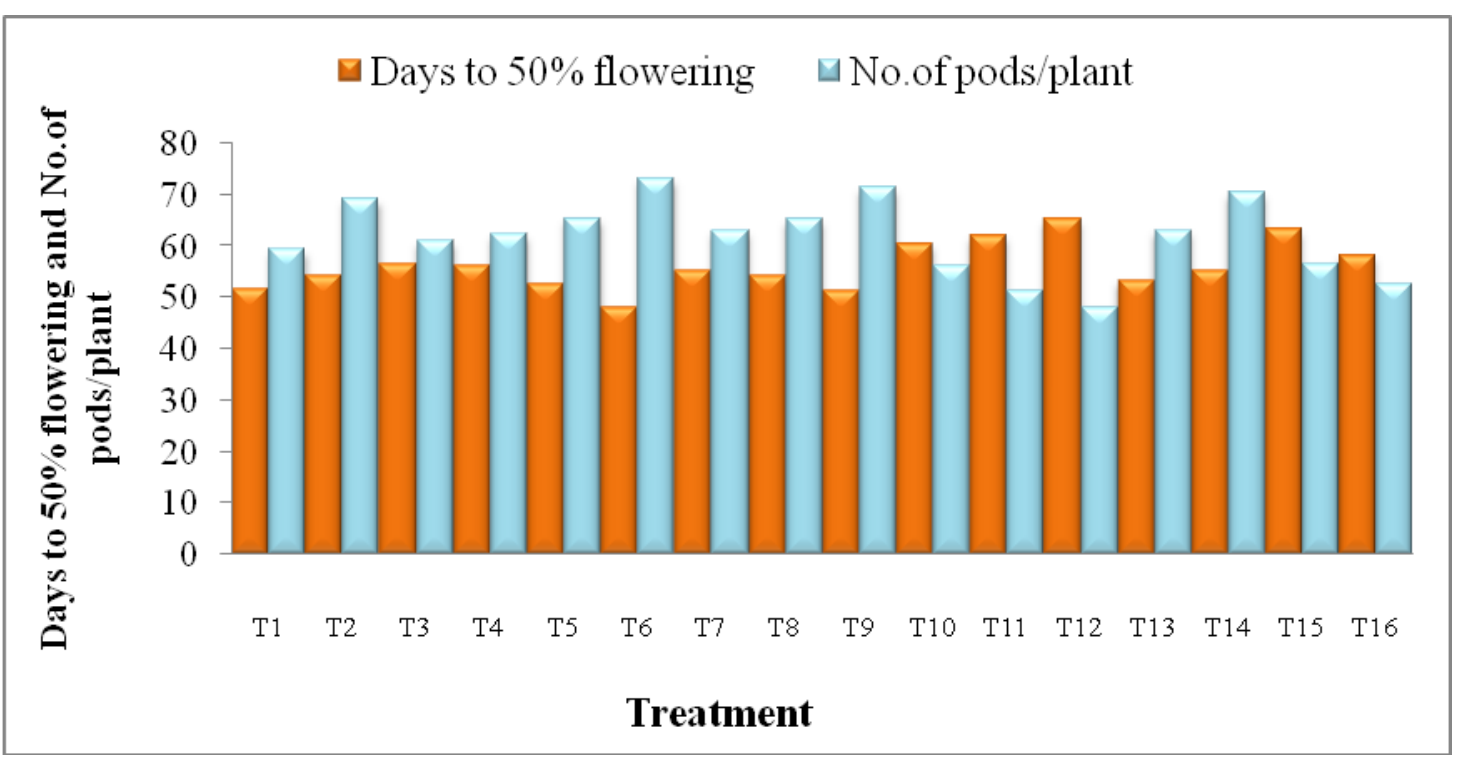

Fig.4 Effect of growth regulators on days to $50 \%$ flowering and number of pods per plant of fenugreek

$\begin{array}{lll}\mathrm{T}_{1}-\mathrm{GA}_{3} 50 \mathrm{ppm} & \mathrm{T}_{2}-\mathrm{GA}_{3} 100 \mathrm{ppm} & \mathrm{T}_{3}-\mathrm{GA}_{3} 150 \mathrm{ppm} \\ \mathrm{T}_{4} \text { - NAA 25 ppm } & \mathrm{T}_{5} \text { - NAA 50 ppm } & \mathrm{T}_{6} \text {-NAA } 75 \mathrm{ppm} \\ \mathrm{T}_{7} \text { - Ethrel } 100 \mathrm{ppm} & \mathrm{T}_{8} \text { - Ethrel } 150 \mathrm{ppm} & \mathrm{T}_{9} \text { - Ethrel } 200 \mathrm{ppm} \\ \mathrm{T}_{10}-\mathrm{MH} 500 \mathrm{ppm} & \mathrm{T}_{11}-\mathrm{MH} 1000 \mathrm{ppm} & \mathrm{T}_{12}-\mathrm{MH} 1500 \mathrm{ppm} \\ \mathrm{T}_{13} \text { - Thiourea 250 ppm } & \mathrm{T}_{14} \text { - Thiourea 500 ppm } & \mathrm{T}_{15} \text {-Thiourea } 750 \mathrm{ppm} \\ \mathrm{T}_{16} \text { - Control } & & \end{array}$

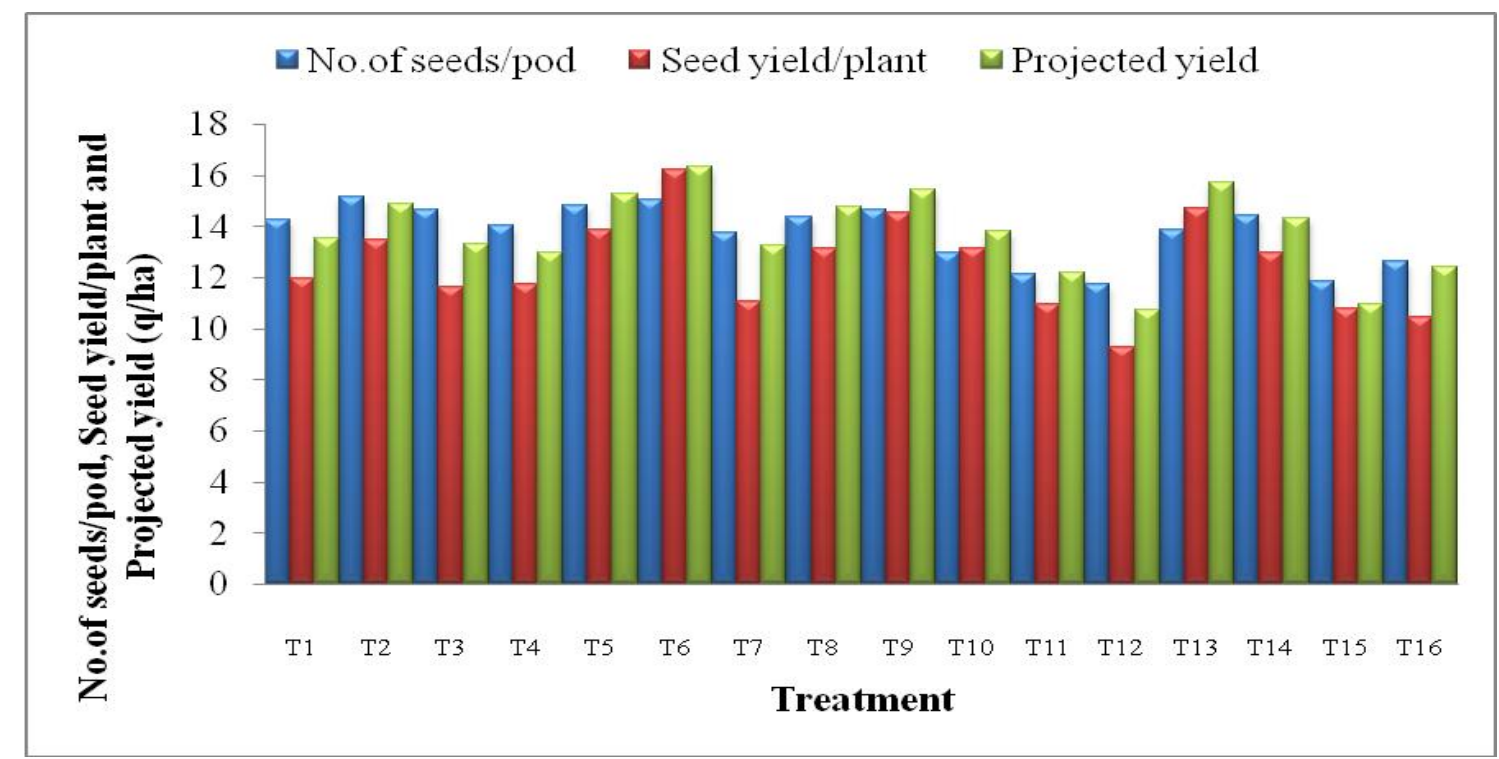

Fig.5 Effect of growth regulators on number of seeds per pod, seed yield per plant and projected

\begin{tabular}{lll} 
& \multicolumn{2}{c}{ yield $(\mathrm{q} / \mathrm{ha}$ ) of fenugreek } \\
$\mathrm{T}_{1}-\mathrm{GA}_{3} 50 \mathrm{ppm}$ & $\mathrm{T}_{2}-\mathrm{GA}_{3} 100 \mathrm{ppm}$ & $\mathrm{T}_{3}-\mathrm{GA}_{3} 150 \mathrm{ppm}$ \\
$\mathrm{T}_{4}$ - NAA $25 \mathrm{ppm}$ & $\mathrm{T}_{5}-\mathrm{NAA} 50 \mathrm{ppm}$ & $\mathrm{T}_{6}-\mathrm{NAA} 75 \mathrm{ppm}$ \\
$\mathrm{T}_{7}$ - Ethrel $100 \mathrm{ppm}$ & $\mathrm{T}_{8}$ - Ethrel $150 \mathrm{ppm}$ & $\mathrm{T}_{9}$ - Ethrel $200 \mathrm{ppm}$ \\
$\mathrm{T}_{10}$ - MH $500 \mathrm{ppm}$ & $\mathrm{T}_{11}-\mathrm{MH} 1000 \mathrm{ppm}$ & $\mathrm{T}_{12}-\mathrm{MH} 1500 \mathrm{ppm}$ \\
$\mathrm{T}_{13}$ - Thiourea $250 \mathrm{ppm}$ & $\mathrm{T}_{14}$ - Thiourea $500 \mathrm{ppm}$ & $\mathrm{T}_{15}$-Thiourea $750 \mathrm{ppm}$ \\
$\mathrm{T}_{16}$ - Control & &
\end{tabular}


Table.1 Effect of growth regulators on growth and yield of fenugreek

\begin{tabular}{|c|c|c|c|c|c|c|c|c|c|c|}
\hline \multirow[t]{2}{*}{ Treatment } & \multicolumn{2}{|c|}{ Plant height (cm) } & \multicolumn{2}{|c|}{$\begin{array}{l}\text { No. of Primary branches } \\
\text { plant }^{-1}\end{array}$} & \multirow{2}{*}{$\begin{array}{c}\text { No. of } \\
\text { Secondary } \\
\text { branches } \\
\text { plant }^{-1} \\
\text { at } 105 \text { DAS }\end{array}$} & \multirow[t]{2}{*}{$\begin{array}{c}\text { Days to } \\
50 \% \\
\text { flowering }\end{array}$} & \multirow[t]{2}{*}{$\begin{array}{l}\text { No. of pod } \\
\text { plant }^{-1}\end{array}$} & \multirow[t]{2}{*}{$\begin{array}{l}\text { No. of seeds } \\
\operatorname{pod}^{-1}\end{array}$} & \multirow[t]{2}{*}{$\begin{array}{l}\text { Seed yield } \\
\text { plant }^{-1}(g)\end{array}$} & \multirow[t]{2}{*}{$\begin{array}{c}\text { Projected } \\
\text { yield (q } \\
\left.\text { ha }^{-1}\right)\end{array}$} \\
\hline & 45 DAS & 105 DAS & 45 DAS & 105 DAS & & & & & & \\
\hline $\mathbf{G A}_{3}-50 \mathrm{ppm}$ & 34.17 & 91.45 & 5.06 & 7.96 & 7.14 & 51.76 & 59.34 & 14.26 & 11.98 & 13.55 \\
\hline $\mathrm{GA}_{3}-100 \mathrm{ppm}$ & 38.24 & 98.32 & 5.41 & 8.24 & 7.83 & 54.28 & 69.24 & 15.18 & 13.45 & 14.85 \\
\hline $\mathbf{G A}_{3}-150 \mathrm{ppm}$ & 41.26 & 94.75 & 5.12 & 7.63 & 7.62 & 56.43 & 61.13 & 14.64 & 11.62 & 13.32 \\
\hline NAA-25 ppm & 31.38 & 89.40 & 4.94 & 7.43 & 7.28 & 56.18 & 62.38 & 14.05 & 11.74 & 12.96 \\
\hline NAA-50 ppm & 34.06 & 96.38 & 5.16 & 7.86 & 7.95 & 52.76 & 65.46 & 14.82 & 13.89 & 15.28 \\
\hline NAA-75 ppm & 37.64 & 92.46 & 5.28 & 8.15 & 7.65 & 48.24 & 73.24 & 15.06 & 16.24 & 16.31 \\
\hline Ethrel-100 ppm & 32.56 & 85.63 & 4.18 & 6.82 & 7.62 & 55.32 & 63.16 & 13.74 & 11.08 & 13.24 \\
\hline Ethrel-150 ppm & 34.72 & 90.48 & 4.56 & 7.13 & 8.38 & 54.16 & 65.28 & 14.36 & 13.15 & 14.76 \\
\hline Ethrel-200 ppm & 38.64 & 93.62 & 4.32 & 7.89 & 8.06 & 51.26 & 71.42 & 14.64 & 14.52 & 15.46 \\
\hline MH-500 ppm & 29.38 & 86.74 & 4.35 & 6.83 & 6.95 & 60.52 & 56.18 & 12.98 & 13.14 & 13.82 \\
\hline MH-1000 ppm & 27.24 & 82.13 & 4.96 & 7.35 & 7.34 & 62.16 & 51.34 & 12.14 & 10.95 & 12.17 \\
\hline MH-1500 ppm & 25.82 & 76.34 & 5.14 & 7.96 & 7.10 & 65.24 & 48.26 & 11.76 & 9.25 & 10.72 \\
\hline $\begin{array}{c}\text { Thiourea-250 } \\
\text { ppm }\end{array}$ & 30.46 & 86.35 & 4.61 & 7.84 & 7.65 & 53.46 & 63.2 & 13.86 & 14.73 & 15.69 \\
\hline $\begin{array}{c}\text { Thiourea-500 } \\
\text { ppm }\end{array}$ & 29.38 & 93.74 & 4.72 & 8.46 & 8.46 & 55.25 & 70.45 & 14.45 & 12.97 & 14.33 \\
\hline $\begin{array}{c}\text { Thiourea-750 } \\
\text { ppm }\end{array}$ & 27.49 & 81.58 & 5.14 & 7.52 & 8.13 & 63.24 & 56.72 & 11.82 & 10.77 & 10.93 \\
\hline Control & 28.65 & 84.36 & 4.67 & 6.47 & 6.73 & 58.24 & 52.74 & 12.62 & 10.46 & 12.38 \\
\hline S.Em. ( \pm$)$ & 0.302 & 0.832 & 0.045 & 0.071 & 0.072 & 0.532 & 0.582 & 0.129 & 0.115 & 0.127 \\
\hline C.D $(P=0.05)$ & 1.205 & 3.326 & 0.177 & 0.281 & 0.281 & 2.126 & 2.324 & 0.355 & 0.459 & 0.503 \\
\hline
\end{tabular}


The role of NAA in enhancing the growth, fruit set and yield attributes in fenugreek has been reported by Alagukannan and Vijayakumar (1999). The present study confirms the earlier reports of Gour et al., (2012). Similar beneficial effect of growth regulators also obtained by Shivran et al., (2016), Krishnaveni et al., (2016), Gour et al., (2010), Bhunia et al., (2006) and Lakshmi et al., (2015) in fenugreek. The possible reason for increased yield was due to higher photosynthetic activity of treated plants as compared to control (Audus, 1960). The better performance of $\mathrm{GA}_{3}$ at $100 \mathrm{ppm}$ over other two concentrations in respect of plant height at 105 DAS, number of primary branches at 45 DAS, number of seed per pod was possibly because of its better efficacy in promoting vegetative and reproductive parameters (Tania et al., 2015).

It is concluded that, among different treatments, shortest duration for $50 \%$ flowering (48.24 days), maximum number of pod plant $^{-1}(73.74)$, yield plant ${ }^{-1}(16.24 \mathrm{~g})$ and projected yield $\mathrm{ha}^{-1}$ (16.31q) were observed with NAA 75 ppm. Plants treated with $\mathrm{GA}_{3}$ $100 \mathrm{ppm}$ recorded maximum plant height $(98.32 \mathrm{~cm})$, primary branches $(5.41)$ at 105 and 45 DAS respectively. Thiourea 500 ppm recorded both maximum number of primary branches (8.46) and secondary branches (8.46). From yield maximization point of view the most effective treatment was NAA 75 ppm (16.31 $\left.\mathrm{qha}^{-1}\right)$ followed by thiourea 250 ppm (15.69 q ha $\left.{ }^{-1}\right)$ and ethrel 200 ppm (15.46 $\mathrm{qha}^{-1}$ ) under alluvial plains of West Bengal for fenugreek production.

\section{References}

Alagukannan, G and Vijayakumar, M. 1999. Effect of plant growth substances on yield attributing parameters, yield and quality in fenugreek (Trigonella foenum-graecum L.). South Indian
Horticulture, 47(1-6):130-133.

Antony A and Gopinathan KP. 1975. Biosynthesis of trigonelline in root cultures of fenugreek (Trigonella foenum-graecum L.). Indian Journal of Experimental Biology 13: 39-41

Audus LJ. 1960. Encyclopaedia of Plant Physiology. Springer, Berlin.3(2):360387

Bhunia SR, Chauhan RPS, Yadav BS and Bhati AS. 2006. Effect of phosphorus, irrigation and Rhizobium on productivity water use and nutrient uptake in fenugreek (Trigonella foenum-graecum L.). Indian Journal of Agronomy51: 239-241

Brummer Y, Cui W and Wang Q. 2003. Extraction, purification and physicochemical characterization of fenugreek gum. Food Hydrocolloids 17:229-236

Fazli FR and Hardman R. 1968.The spice fenugreek (Trigonella foenum-graecum L), its commercial varieties of seed as a source of diosgenin.Tropical Science, 10(2): 68-78.

Fowden L, Pratt HM and Smith A. 1973. 4hydroxyisoleucine from seed of Trigonella foenum-graecumL. Phytochemistry12:1701-07.

Gour K, Patel BS and Mehta RS.2012. Yield and nodulation of fenugreek (Trigonella foenum-graecum). International Journal of Seed Spices3:42-45

Krishnaveni V, Padmalatha T, Padma SSV and Prasad ALN. 2016. Influence of pinching and plant growth regulators on flowering, yield and economics of fenugreek (Trigonella foenum-graecum L.). Journal of Spices and Aromatic Crops, 25(1): 41-48.

Lakshmi J, Gowda R., Parashivamurthy, Narayanaswamy $S$ and Shivanandam VN. 2015. Influence of pre-flowering pinching and maleic hydrazide spray on plant growth, seed yield and quality 
attributes in fenugreek. Legume Research-An International Journal., 38(3): 353-357.

Petropoulos GA. 1973. Agronomic, genetic and chemical studies of Trigonella foenum-graecum L. PhD. Thesis Submitted to Diss. Bath University, England.

Sastry EVD and Anandraj M. 2013. Cumin, fennel and fenugreek soils, plant growth and crop production. In: Soils, Plant Growth and Crop Production (vol. 1-3), Willy H. Verheye (Ed.), Encyclopedia of Life Support Systems.

Saxena OP. 1989.Role of plant growth regulators in plant productivity studies. In: Proc. Nat. Sem. on Strategies in Physiological Regulation of Pl. Productivity, 27-29 December,
Bombay, India, pp.13-17

Shivran AC, Jat NL, Singh D, Sastry EVD and Rajput S. 2016 .Response of fenugreek (Trigonella foenum-graecum L.) to plant growth regulators and their time of application. Journal of Spices and Aromatic Crops, 25 (2): 169-174

Spice board. 2015. Annual Report of 2014-15, Cochin.

Tania C, Kumara JNU, Chatterjee R. and Chattopadhyay PK. 2015. Influence of gibberellic acid on growth and quality of fenugreek (Trigonella foenumgraecum L.). Journal of Spices and Aromatic Crops, 24(1): 56-57.

Witter CD. 1971 Evaluation of cytozymes as foliar application to enhance cotton yields. Arkanson Farm Research29:2

\section{How to cite this article:}

Peddaveeri Pravalika Reddy and J.K. Hore. 2020. Role of Growth Regulators on Fenugreek (Trigonella foenum-graecum L.). Int.J.Curr.Microbiol.App.Sci. 9(07): 25-32. doi: https://doi.org/10.20546/ijcmas.2020.907.004 